\title{
Microwave Solvent-free Synthesis of Some Bioactive 3-(2,5-Dimethylfuran-3-yl)-pyrazoline Derivatives and their Antimicrobial Activity
}

\author{
S. KULATHOORAN ${ }^{1}$, T. VADIVEL ${ }^{1}$, M. DHAMODARAN ${ }^{2 *}$ and B. SELVAKUMAR ${ }^{3}$ \\ ${ }^{1}$ Research \& Development Centre, Bharathiar University, Coimbatore-641046, India. \\ ${ }^{2}$ Department of Chemistry, Perunthalaivar Kamarajar Institute of Engineering and Technology, \\ Karaikal-609603, India. \\ ${ }^{3}$ Department of Chemistry, PG and Research Centre, Sriparamakalyani College, \\ Alwarkurichi 627412, India. \\ ${ }^{*}$ Corresponding author E-mail: dhamu_762003@yahoo.co.in \\ http://dx.doi.org/10.13005/ojc/320232
}

(Received: November 28, 2015; Accepted: December 31, 2015)

\begin{abstract}
A series of some new 1-thiocarbamoyl-3-(2,5-dimethylfuran-3-yl)-5-(fluoro/trifluoromethylphenyl) -2-pyrazolines 4a-f have been synthesized by treating with various fluoro/trifluoromethyl substituted chalcones, thiosemicarbazide and potassium carbonate using conventional heating and solventfree microwave irradiation techniques. The easy work-up of the products, rapid reaction and mild conditions are noticeable features of this protocol. Synthesized compounds have been screened for their in vitro antimicrobial activity against six microbial strains. Among them, 1-Thiocarbamoyl3-(2,5-dimethylfuran-3-yl)-5-(3-fluorophenyl)-2-pyrazoline 4b showed maximum zone of inhibition against all the tested microorganisms. Structural elucidation of the synthesized compounds were determined on the basis of various spectroscopic methods.
\end{abstract}

Keywords: Microwave Solvent-free Reaction, Solid-phase Synthesis, Chalcones, Pyrazolines, Antimicrobial activity.

\section{INTRODUCTION}

Increasing evidence suggests that pyrazoline derivatives possess a broad spectrum of biological activities antibacterial ${ }^{1-2}$, antifunga| $\left.\right|^{3-4}$ and pharmacological activities such as antiinflammatory ${ }^{5-6}$, antitubercular ${ }^{7}$, anticancer ${ }^{8}$, analgesic ${ }^{9}$, antipyretic ${ }^{10}$ and anticonvulsant ${ }^{11}$. Based on the above study, we need to develop new drug against antimicrobial activities. Therefore, we were led to identify new approaches of pyrazoline derivatives as well as test the antimicrobial activity. Typically, synthesis of organic compounds using conventional method are found to take several hours 
to days to complete but with microwave assisted organic synthesis it takes few minutes ${ }^{12}$. The wide applicability of microwave activation in the chemical reactions is due to cleaner products, higher yield, shorter reaction time, operational simplicity, safe and minimization of side reactions ${ }^{13-14}$. In recent years the microwave reaction conditions on a inorganic base support is a promising alternative to conventional methods as these reactions represent a clean, efficient, economical and eco-friendly procedure ${ }^{15}$.

In continuation of our interest in the synthesis of various pyrazoline derivatives using conventional heating and microwave solvent-free techniques ${ }^{16}$ by telescopic method, it was our effort to develop an efficient method for synthesis of pyrazoline derivatives by using an inexpensive, safe, simple and common reagent. Alkali metal carbonates are weak bases and they are nontoxic in nature. Thus, the development of new methods that lead to convenient procedures with very short time period and better yields are of interest. Under the framework of green chemistry, we have developed an environmentally benign solvent-free approach for the synthesis of pyrazoline derivatives using potassium carbonate as an effective, economical and eco-friendly base catalyst. This expeditious and solvent free approach involves the exposure of neat reactants to microwave (MW) irradiation in conjunction with the use of supported reagents ${ }^{17}$.

\section{EXPERIMENTAL}

Melting points were determined using a Büchi apparatus. IR spectra were recorded for $\mathrm{KBr}$ disc on a Mattson 5000 FTIR spectrometer. All of the commercial chemicals and solvents were of reagent grade and were used without further purification. ${ }^{1} \mathrm{H}$ and ${ }^{13} \mathrm{C}$ NMR spectra were measured on a Bruker WP $400 / 75 \mathrm{MHz}$ in DMSO- $d_{6}$ as solvent, using tetramethylsilane as internal standard, chemical shifts are expressed as ppm and $J$ values are given in $\mathrm{Hz}$. Mass spectrometric data were determined using an Agilent 6890 series instrument. The progress of the reaction was monitored by TLC using aluminum silica gel plates $60 \mathrm{~F}_{245}$. Products were purified by column chromatography using silica gel (60-120 mesh).

\section{General procedure for the synthesis of 3-acetyl- 2,5-dimethylfuran (2)}

A stirred mixture of acetylacetone $(2 \mathrm{~g}$, 0.02 mole) in toluene $(5 \mathrm{ml})$, propargyl bromide (2.37g, 0.02 mole), 1,8-diazabicyclo[5.4.0]undec7 -ene $(6.08 \mathrm{~g}, 0.04$ mole) and a catalytic amount of Cul $\left(0.37 \mathrm{~g}, 0.002\right.$ mole) was heated to $90^{\circ} \mathrm{C}$ under nitrogen atmosphere for $5 \mathrm{hrs}$. Solvents were removed and the residue was subjected to the column chromatography using silica gel eluting with $10 \%$ mixture of ethyl acetate and $n$-heptane to obtain a title compound (2), which was confirmed by IR, ${ }^{1} \mathrm{H}$,

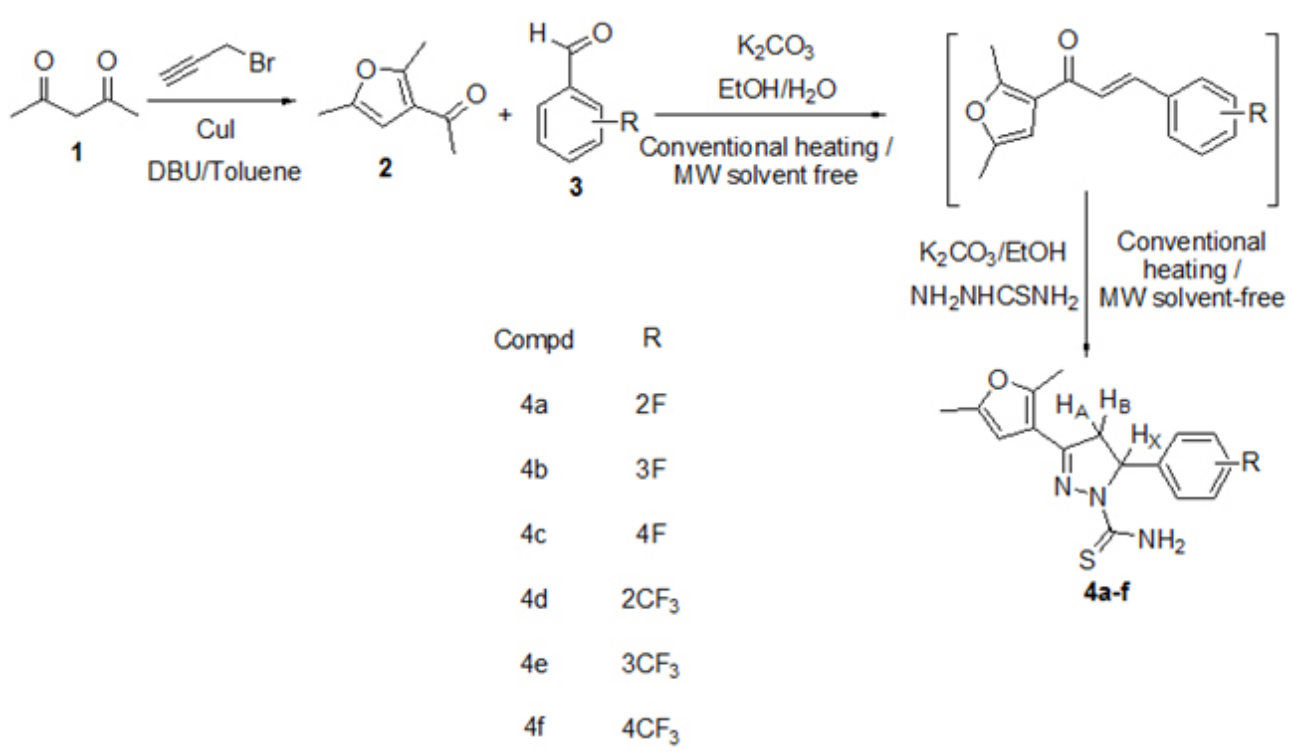

Scheme 1: Synthesis of 3-(2,5-dimethylfuran-3-yl)-pyrazoline derivatives 4a-f 
${ }^{13} \mathrm{C}$ NMR and mass spectral studies ${ }^{18} .{ }^{1} \mathrm{H}-\mathrm{NMR}(400$ $\mathrm{MHz}$, DMSO- $\left.d_{6}, \delta, \mathrm{ppm}\right): 2.21\left(\mathrm{~s}, 3 \mathrm{H}, \mathrm{CH}_{3}\right), 2.25$ (s, $\left.3 \mathrm{H}, \mathrm{CH}_{3}\right), 2.42\left(\mathrm{~s}, 3 \mathrm{H},-\mathrm{COCH}_{3}\right), 6.09$ (s, 1H, furyl-H). ${ }^{13} \mathrm{C}$ NMR $\left(75.46 \mathrm{MHz}\right.$, DMSO- $\left.d_{6}, \delta, \mathrm{ppm}\right) 189.42$, 159.14, 152.70, 124.40, 106.24, 34.65, 14.64, 13.42. IR $\left(\mathrm{KBr}, v \mathrm{~cm}^{-1}\right): 1664(\mathrm{C}=\mathrm{O})$. MS (ESI) m/z: 139.2 $(\mathrm{M}+\mathrm{H})^{+}$.

\section{General procedure for the synthesis of pyrazoline derivatives $4(a-f)$ using conventional heating method}

A mixture of potassium carbonate $(5 \mathrm{~g}, 0.0362 \mathrm{~mole})$ in water $(2 \mathrm{~mL})$, minimal amount of ethanol (1 mL), 3-acetyl-2,5-dimethylfuran (2g, 0.0144 mole) and 2-fluorobenzaldehyde (1.8g, 0.0144 mole) was stirred at room temperature $\left(29^{\circ} \mathrm{C}\right)$ for 10 minutes. Temperature of the reaction mass was increased to $45-50{ }^{\circ} \mathrm{C}$ and stirred vigorously for $1-2 \mathrm{~h}$. Progress of the reaction was monitored by TLC and cooled to RT. To this mixture, thiosemicarbazide (1.6g, 0.0173 mole) and ethanol $(10 \mathrm{ml})$ was added and stirred at refluxtemperature for 5-6 h. Progress of the reaction was monitored by TLC and cooled to RT. To the reaction mixture, ice-cold water was added and stirred well to remove the potassium carbonate present in the reaction mixture. The reddish yellow 1-Thiocarbamoyl-3-(2,5dimethylfuran-3-yl)-5-(2-fluorophenyl)-2-pyrazoline was filtered at the pump, washed with ice-cold water and crystalized from ethanol. The above general method was adopted for the synthesis of compounds $4 b-f$ of this series.

\section{General procedure for the synthesis of pyrazoline derivatives $4(a-f)$ under the solvent- free microwave irradiation method}

A mixture of 2 -fluorobenzaldehyde $(0.45 \mathrm{~g}$, 0.0036 mole), 3-acetyl-2,5-dimethylfuran $(0.5 \mathrm{~g}$, 0.0036 mole) and solid $\mathrm{K}_{2} \mathrm{CO}_{3}(1.24 \mathrm{~g}, 0.0090$ mole) was ground with a mortar and pestle at room temperature. Further, it was subjected to microwave irradiation at $600 \mathrm{~W}$ in sealed vessel for 2-3 minutes, monitoring the progress of reaction by TLC. To this was, added thiosemicarbazide $(0.40 \mathrm{~g}, 0.0044 \mathrm{~mole})$, stirred with glass rod at room temperature $\left(29^{\circ} \mathrm{C}\right)$ and subjected to microwave irradiation at $600 \mathrm{~W}$ in sealed vessel for 5-8 minutes, monitoring the progress of reaction by TLC. The reaction mixture was quenched with ice-cold water and filtered at the pump, followed by wash with ice-cold water and crystalized from ethanol to obtain reddish yellow 1-Thiocarbamoyl3-(2,5-dimethylfuran-3-yl)-5-(2-fluorophenyl)-2pyrazoline. The above general method was adopted for the synthesis of compounds $\mathbf{4 b - f}$ of this series.

\section{Determination of antimicrobial activity}

The antimicrobial activity of the synthesized compounds were evaluated by Agar well-diffusion method $^{19-20}$. All the compounds were tested at different concentration level, DMSO was used as both solvent and control. The inhibition zone diameter in $\mathrm{mm}$ (IZD) was used as a criterion for the antimicrobial activity. The lowest concentration required to arrest the growth of microorganism was regarded as minimum inhibitory concentration (MIC, $\mu \mathrm{g} / \mathrm{mL}$ ) were determined for all the compounds and compared with the reference standard. The antimicrobial activities were assayed biologically using diffusion plate technique. The experiments were done by pouring a spore suspension $10^{6}$ colonforming units (CFU) per $\mathrm{mL}$ of the test strain to 75 $\mathrm{mL}$ of nutrient agar medium at $45^{\circ} \mathrm{C}$ and mixed well, and poured into a $15 \mathrm{~cm}$ sterile metallic petri plate. The medium was allowed to solidify and $8 \mathrm{~mm}$ wells were dug with a sterile metallic borer, then DMSO solution of the test sample $(1 \mathrm{~mL})$ at $1 \mu \mathrm{g} / \mathrm{mL}$ was added to the respective wells. DMSO was used as negative control. The layer was allowed to set for 30 minutes and incubated at $37^{\circ} \mathrm{C}$ for $48 \mathrm{~h}$ and results were noted.

\section{RESULTS AND DISCUSSION}

3-acetyl-2,5-dimethylfuran was synthesized from commercially available acetylacetone. 3-Acetyl2,5-dimethylfuran in a Claisen-Schmidt condensation with various fluoro/trifluoromethylbenzaldehydes and ethanol in the presence of $\mathrm{K}_{2} \mathrm{CO}_{3}$ using conventional heating and solvent-free microwave techniques to obtain desired chalcones. Further, it was treated with thiosemicarbazide without work-up and purification as a telescopic process to obtain 1-thiocarbamoyl-3-(2,5-dimethylfuran-3yl)-5-(fluoro/trifluoromethylphenyl)-2-pyrazolines 4a-f using conventional heating and solvent-free microwave irradiation techniques ${ }^{21}$. The reaction time required for the synthesis of compounds $4 a-f$ by the conventional method was 5-6 h, whereas the reaction time has been drastically brought down to 5-8 minutes with improved yields under solvent free 
microwave irradiation condition. Comparative studies were performed between conventional heating and solvent-free microwave methods and the results were presented in Table 1.

Newly synthesized pyrazoline derivatives 4a-f were characterized by $\mathrm{IR},{ }^{1} \mathrm{H},{ }^{13} \mathrm{C}$ and mass spectral studies. The structures of pyrazolines were assigned based on detailed spectroscopic analysis. The IR spectrum of the compounds afforded pyrazoline $\mathrm{C}=\mathrm{N}$ stretching (1569-1600 $\mathrm{cm}^{-1}$ ), thiocarbamoyl group N-H stretching (3458$\left.3247 \mathrm{~cm}^{-1}\right), \mathrm{C}^{4}-\mathrm{H}$ deformation (1367-1483), $\mathrm{C}^{5}-\mathrm{N}^{1}$ stretching (1064-1149) and thiocarbamoyl group $\mathrm{C}=\mathrm{S}$ stretching $1324-1358 \mathrm{~cm}^{-1}$ bands. In the ${ }^{1} \mathrm{H}$ NMR spectra of the compounds $\mathrm{H}_{A}, \mathrm{H}_{B}$ and $\mathrm{H}_{X}$ protons of the pyrazoline ring were observed as doublet of doublet at $\delta$ 2.96-3.07 $\left(J_{A B}: 17.19-17.73\right.$ $\mathrm{Hz})$, 3.83-3.96 $\left(J_{A X}: 4-10 \mathrm{~Hz}\right)$ and 5.83-6.10 ppm $\left(J_{B X}:\right.$ $11.61-11.67 \mathrm{~Hz}$ ), respectively. $\mathrm{NH}_{2}$ protons of the thiocarbamoyl group were seen at 7.54-8.02 ppm generally as broad bands, along with resonance in its ${ }^{13} \mathrm{C}$ NMR at $\delta 175.36$ indicating the presence of $\mathrm{C}=\mathrm{S}$ function. In the mass spectra of the compounds molecular ion $\left(\mathrm{M}^{+}\right)$and $\mathrm{M}^{+2}$ were observed.

\section{Antibacterial activity}

The antibacterial activities of the synthesized compounds $4 \mathrm{a}-\mathrm{f}$ were determined in vitro against three bacterial strains Klebsiella pneumonia ATCC13883, Staphylococcus aureus ATCC-25923 and

\section{Table 1: Synthesis of pyrazoline derivatives 4a-f by conventional and microwave irradiation techniques}

\begin{tabular}{lccccc}
\hline & \multicolumn{3}{c}{ Conventional } & \multicolumn{3}{c}{ MW } & \\
\cline { 5 - 6 } Comp. Time & $\begin{array}{c}\text { Yield }^{a} \\
(\%)\end{array}$ & $\begin{array}{c}\text { Time } \\
(\mathbf{m i n})\end{array}$ & $\begin{array}{c}\text { Yield }^{\mathrm{a}} \\
(\%)\end{array}$ & $\begin{array}{c}\mathbf{M}_{\mathrm{p}}^{\mathrm{b}} \\
\left({ }^{\circ} \mathbf{C}\right)\end{array}$ \\
\hline $4 \mathrm{a}$ & $5 \mathrm{~h}$ & 59 & 5 & 73 & $176-178$ \\
$4 \mathrm{~b}$ & $5 \mathrm{~h}$ & 63 & 5 & 81 & $138-140$ \\
$4 \mathrm{c}$ & $5 \mathrm{~h}$ & 54 & 5 & 76 & $178-180$ \\
$4 \mathrm{~d}$ & $5 \mathrm{~h}$ & 56 & 5 & 84 & $139-140$ \\
$4 \mathrm{e}$ & $5 \mathrm{~h}$ & 64 & 5 & 69 & $174-176$ \\
$4 \mathrm{f}$ & $5 \mathrm{~h}$ & 61 & 5 & 78 & $164-166$ \\
\hline
\end{tabular}

alsolated yield buncorrected
Escherichia coli ATCC-9637 at $50 \mu \mathrm{g} / \mathrm{mL}$. The zone of inhibition was measured in $\mathrm{mm}$ and Ciprofloxacin used as standard antibacterial substance, under similar conditions for comparison. All the synthesized compounds have shown moderate to good activity against the tested microorganisms (Table 2). Among all, compound $4 \mathrm{~b}$ shown maximum zone of inhibition against K. Pneumonia, S. Aureus and E. colicompared with their reference standard. Compound $4 \mathrm{~d}$ and $4 \mathrm{e}$ also showed excellent potent against $K$. Pneumonia. Similarly, compound $4 \mathrm{c}, 4 \mathrm{e}$ and $4 \mathrm{f}$ also showed significant activity against $E$. coli. It concludes that, changing the fluoro and trifluoromethyl substitution in phenyl ring doesn't provide any significant changes in antibacterial activity except fluorine substituted in $m$-position of phenyl ring.

\section{Antifungal activity}

The antifungal activity of the compounds 4a-f were tested against three pathogenic fungi, Candida albicans ATCC-28366, Rhizopus arrhizus ATCC-11145 and Aspegillus niger ATCC-26036 at 50 $\mu \mathrm{g} / \mathrm{mL}$ concentration and the results were compared with Fluconazole as a reference standard. All the synthesized compounds have shown moderate to good activity against the tested microorganisms (Table 2). Among all, compound $4 \mathrm{~b}$ shown maximum zone of inhibition against Candida albicans and Aspegillus niger. We observed that, fluorine substitution in $m$-position of phenyl ring observed significant activity than other compounds.

The lowest concentration required to arrest the growth of microorganism was regarded as minimum inhibitory concentration (MIC, $\mu \mathrm{g} / \mathrm{mL}$ ) were determined for all the compounds $4 a-f$ and compared with the reference standard. The result of the MIC determinations reported in Table 2 showed that compound $4 \mathrm{~b}$ exhibited broad spectrum action against $K$. Pneumonia, S. aureus, E. coli and $C$. Albicans and $A$. Niger compared with the reference standard. Compound $4 \mathrm{c}$ showed significant activity with MIC values of 1.9 and $7.2 \mu \mathrm{g} / \mathrm{m}$ Lagainst $E$. coli and $R$. Arrhizus, respectively. Compounds $4 \mathrm{~d}$ and $4 \mathrm{f}$ displayed high activity against $K$. pneumonia, S. Aureus with MIC values of 8.7 and $7.4 \mu \mathrm{g} / \mathrm{mL}$, respectively. 
Analytical data

1-Thiocarbamoyl-3-(2,5-dimethylfuran-3-yl)-5-(2fluorophenyl)-2-pyrazoline (4a)

${ }^{1} \mathrm{H}$ NMR (300 MHz, DMSO- $\left.d_{6}, \delta, \mathrm{ppm}\right)$ : 2.20 (s, 3H, $\left.\mathrm{CH}_{3}\right), 2.41$ (s, 3H, $\left.\mathrm{CH}_{3}\right), 2.97(1 \mathrm{H}$, dd, pyrazoline $\left.\mathrm{H}_{\mathrm{A}}, \mathrm{J}_{\mathrm{AB}}: 17.19 \mathrm{~Hz}, \mathrm{~J}_{\mathrm{AX}}: 3.61 \mathrm{~Hz}\right), 3.87$ $\left(1 \mathrm{H}\right.$, dd, pyrazoline $\left.\mathrm{H}_{\mathrm{B}}, \mathrm{J}_{\mathrm{AB}}: 17.6 \mathrm{~Hz}, \mathrm{~J}_{\mathrm{BX}}: 11.61 \mathrm{~Hz}\right)$, $5.96\left(1 \mathrm{H}\right.$, dd, pyrazoline $\mathrm{H}_{\mathrm{X}}, \mathrm{J}_{\mathrm{Ax}}: 3.6 \mathrm{~Hz}, \mathrm{~J}_{\mathrm{BX}}: 11.61$ $\mathrm{Hz}), 6.97$ (s, $1 \mathrm{H}$, furyl-H), 6.95-6.97 (m, $1 \mathrm{H}, \mathrm{Ar}-\mathrm{H})$, 7.00-7.28 (m, 3H, Ar-H), 7.57 (b, 1H, NH), 7.95 (b, $1 \mathrm{H}, \mathrm{NH}) .{ }^{13} \mathrm{C}$ NMR $\left(75.46 \mathrm{MHz}\right.$, DMSO- $\left.d_{6}, \delta, \mathrm{ppm}\right)$ : $173.20,159.50,151.21,150.23,149.34,129.04$, $128.54,124.53,115.24,113.21,108.46,106.42$, 56.31, 47.56, 14.71, 13.41. IR ( $\left.\mathrm{KBr}, \mathrm{v} \mathrm{cm}^{-1}\right)$ : 3387 , 1582, 1478, 1401, 1365, $1096 \mathrm{~cm}^{-1}$ HR mass Calcd. for $\mathrm{C}_{16} \mathrm{H}_{16} \mathrm{FN}_{3}$ OS: 317.28. Found: $m / z 318.3$ $(\mathrm{M}+\mathrm{H})^{+}$.

1-Thiocarbamoyl-3-(2,5-dimethylfuran-3-yl)-5-(3fluorophenyl)-2-pyrazoline (4b)

${ }^{1} \mathrm{H}$ NMR (300 MHz, DMSO- $\left.d_{6}, \delta, \mathrm{ppm}\right)$ : $2.19\left(\mathrm{~s}, 3 \mathrm{H}, \mathrm{CH}_{3}\right), 2.41\left(\mathrm{~s}, 3 \mathrm{H}, \mathrm{CH}_{3}\right), 2.97(1 \mathrm{H}$, dd, pyrazoline $\left.\mathrm{H}_{\mathrm{A}}, \mathrm{J}_{\mathrm{AB}}: 17.73 \mathrm{~Hz}, \mathrm{~J}_{\mathrm{AX}}: 3.61 \mathrm{~Hz}\right), 3.83(1 \mathrm{H}$, dd, pyrazoline $\left.\mathrm{H}_{\mathrm{B}}, \mathrm{J}_{\mathrm{AB}}: 17.6 \mathrm{~Hz}, \mathrm{~J}_{\mathrm{BX}}: 11.61 \mathrm{~Hz}\right), 5.86$ $\left(1 \mathrm{H}\right.$, dd, pyrazoline $\left.\mathrm{H}_{\mathrm{X}}, \mathrm{J}_{\mathrm{Ax}}: 3.6 \mathrm{~Hz}, \mathrm{~J}_{\mathrm{BX}}: 11.61 \mathrm{~Hz}\right)$, 6.37 (s, 1H, furyl-H), 6.86-6.94 (m, 2H, Ar-H), 7.01$7.06(\mathrm{~m}, 1 \mathrm{H}, \mathrm{Ar}-\mathrm{H}), 7.31-7.38(\mathrm{~m}, 1 \mathrm{H}, \mathrm{Ar}-\mathrm{H}), 7.58$ (b, $1 \mathrm{H}, \mathrm{NH}), 7.97$ (b, $1 \mathrm{H}, \mathrm{NH}) .{ }^{13} \mathrm{C}$ NMR $(75.46 \mathrm{MHz}$, DMSO- $d_{6}, \delta$, ppm): 174.90, 162.50, 151.80, 150.23,
$149.70,145.10,130.24,122.04,114.24,113.51$, 113.12, 107.26, 66.31, 47.56, 14.71, 13.41. IR (KBr, $\left.\mathrm{v} \mathrm{cm}^{-1}\right)$ : 3482, 1595, 1483, 1449, 1363, $1008 \mathrm{~cm}^{-1}$. $\mathrm{HR}$ mass Calcd. for $\mathrm{C}_{16} \mathrm{H}_{16} \mathrm{FN}_{3} \mathrm{OS}: 317.28$. Found: $m / z 319.3(\mathrm{M}+\mathrm{H})^{2+}$.

1-Thiocarbamoyl-3-(2,5-dimethylfuran-3-yl)-5-(4fluorophenyl)-2-pyrazoline (4c)

${ }^{1} \mathrm{H}$ NMR (300 MHz, DMSO- $\left.d_{6}, \delta, \mathrm{ppm}\right)$ : $2.20\left(\mathrm{~s}, 3 \mathrm{H}, \mathrm{CH}_{3}\right), 2.41\left(\mathrm{~s}, 3 \mathrm{H}, \mathrm{CH}_{3}\right), 2.97(1 \mathrm{H}, \mathrm{dd}$, pyrazoline $\left.\mathrm{H}_{\mathrm{A}}, \mathrm{J}_{\mathrm{AB}}: 17.6 \mathrm{~Hz}, \mathrm{~J}_{\mathrm{AX}}: 3.67 \mathrm{~Hz}\right), 3.83(1 \mathrm{H}$, dd, pyrazoline $\mathrm{H}_{B}, J_{A B}: 17.6 \mathrm{~Hz}, \mathrm{~J}_{B X}: 11.64 \mathrm{~Hz}$ ), 5.83 $\left(1 \mathrm{H}\right.$, dd, pyrazoline $\left.\mathrm{H}_{\mathrm{x}}, \mathrm{J}_{\mathrm{Ax}}: 3.6 \mathrm{~Hz}, \mathrm{~J}_{\mathrm{BX}}: 11.64 \mathrm{~Hz}\right)$, 6.37 (s, $1 \mathrm{H}$, furyl-H), 7.11-7.13 (m, 4H, Ar-H), 7.54 (b, $1 \mathrm{H}, \mathrm{NH}), 7.91$ (b, $1 \mathrm{H}, \mathrm{NH}) .{ }^{13} \mathrm{C}$ NMR $(75.46 \mathrm{MHz}$, DMSO- $\left.d_{6}, \delta, \mathrm{ppm}\right): 175.90,160.90,151.81,150.73$, $149.74,139.14,128.60,115.53,115.24,113.12$, 107.16, 106.42, 66.13, 41.56, 14.71, 13.41. IR $(\mathrm{KBr}$, $\left.\mathrm{v} \mathrm{cm}^{-1}\right)$ : 3479, $1600,1481,1420,1358,1084 \mathrm{~cm}^{-1}$. HR mass Calcd. for $\mathrm{C}_{16} \mathrm{H}_{16} \mathrm{FN}_{3} \mathrm{OS}$ : 317.28. Found: $\mathrm{m} / \mathrm{z} 318.1(\mathrm{M}+\mathrm{H})^{+}$.

1-Thiocarbamoyl-3-(2,5-dimethylfuran-3-yl)-5-(2(trifluoromethyl)phenyl)-2-pyrazoline (4d)

${ }^{1} \mathrm{H}$ NMR (300 MHz, DMSO- $\left.d_{6}, \delta, p p m\right)$ : $2.20\left(\mathrm{~s}, 3 \mathrm{H}, \mathrm{CH}_{3}\right), 2.42\left(\mathrm{~s}, 3 \mathrm{H}, \mathrm{CH}_{3}\right), 2.96(1 \mathrm{H}, \mathrm{dd}$, pyrazoline $\left.H_{A}, J_{A B}: 17.6 \mathrm{~Hz}, J_{A x}: 3.61 \mathrm{~Hz}\right), 3.96(1 \mathrm{H}$, dd, pyrazoline $\left.\mathrm{H}_{B}, J_{A B}: 17.5 \mathrm{~Hz}, \mathrm{~J}_{B X}: 11.67 \mathrm{~Hz}\right), 6.10$ $\left(1 \mathrm{H}\right.$, dd, pyrazoline $\left.\mathrm{H}_{\mathrm{X}}, \mathrm{J}_{\mathrm{Ax}}: 3.6 \mathrm{~Hz}, \mathrm{~J}_{\mathrm{BX}}: 11.67 \mathrm{~Hz}\right)$,

Table 2: Antimicrobial activity of isolated products $4 a-f$

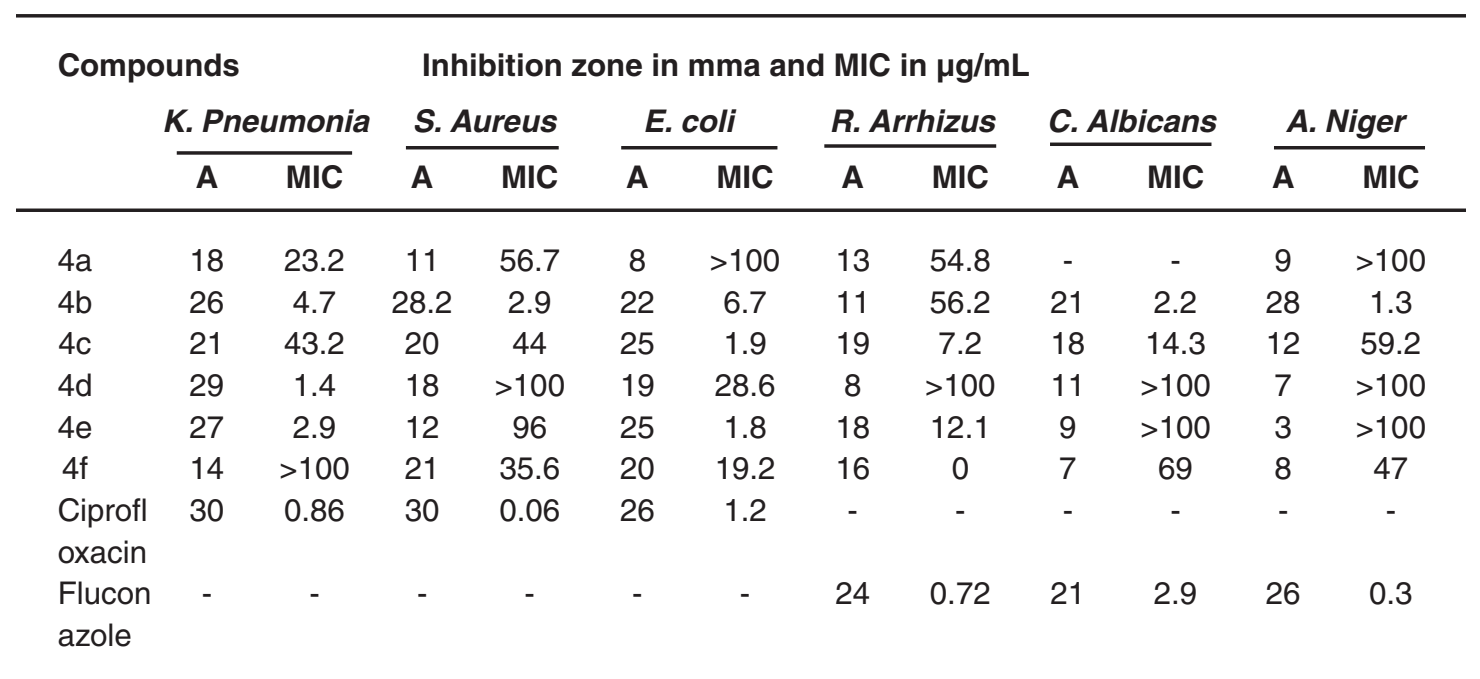

aZone of inhibition in mm; MIC: minimum inhibition concentration values are reported in $\mu \mathrm{g} / \mathrm{mL}$ 
$6.38(\mathrm{~s}, 1 \mathrm{H}$, furyl-H), 7.44-7.47 (m, 1H, Ar-H), 7.59$7.63(\mathrm{~m}, 2 \mathrm{H}, \mathrm{Ar}-\mathrm{H}), 7.65$ (b, 1H, NH), 7.72-7.74 (m, $1 \mathrm{H}, \mathrm{Ar}-\mathrm{H}), 8.02$ (b, $1 \mathrm{H}, \mathrm{NH}) .{ }^{13} \mathrm{C}$ NMR $(75.46 \mathrm{MHz}$, DMSO- $\left.d_{6}, \delta, \mathrm{ppm}\right): 175.20,151.81,150.73,149.74$, $138.01,131.94,127.54,127.30,125.81,125.01$, 119.14, 107.26, 106.42, 59.61, 41.41, 14.71, 13.41. IR $\left(\mathrm{KBr}, \mathrm{v} \mathrm{cm}^{-1}\right): 3450,1579,1483,1422,1306$, $1057 \mathrm{~cm}^{-1}$. HR mass Calcd. for $\mathrm{C}_{17} \mathrm{H}_{16} \mathrm{~F}_{3} \mathrm{~N}_{3} \mathrm{OS}: 367.1$. Found: $m / z 368.1(\mathrm{M}+\mathrm{H})^{+}$.

1-Thiocarbamoyl-3-(2,5-dimethylfuran-3-yl)-5-(3(trifluoromethyl)phenyl)-2-pyrazoline (4e)

${ }^{1} \mathrm{H}$ NMR (300 MHz, DMSO- $\left.d_{6}, \delta, \mathrm{ppm}\right)$ : 2.22 (s, 3H, $\mathrm{CH}_{3}$ ), 2.44 (s, 3H, $\left.\mathrm{CH}_{3}\right), 3.07(1 \mathrm{H}$, dd, pyrazoline $\left.\mathrm{H}_{\mathrm{A}}, \mathrm{J}_{\mathrm{AB}}: 17.7 \mathrm{~Hz}, \mathrm{~J}_{\mathrm{AX}}: 3.67 \mathrm{~Hz}\right), 3.91(1 \mathrm{H}$, dd, pyrazoline $\left.\mathrm{H}_{B}, J_{A B}: 17.9 \mathrm{~Hz}, \mathrm{~J}_{\mathrm{BX}}: 11.61 \mathrm{~Hz}\right), 5.98$ $\left(1 \mathrm{H}\right.$, dd, pyrazoline $\left.\mathrm{H}_{\mathrm{X}}, \mathrm{J}_{\mathrm{Ax}}: 3.67 \mathrm{~Hz}, \mathrm{~J}_{\mathrm{BX}}: 11.61 \mathrm{~Hz}\right)$, 6.40 (s, $1 \mathrm{H}$, furyl-H), 7.39-7.46 (m, 2H, Ar-H), 7.557.60 (m, 3H, Ar-H), 7.62 (b, 1H, NH), 7.99 (b, 1H, NH). ${ }^{13} \mathrm{C}$ NMR (75.46 MHz, DMSO- $\left.d_{6}, a ̈, p p m\right): 175.90$, $151.80,150.73,149.74,143.81,130.84,130.13$, 128.94, 124.90, 125.81, 124.51, 113.14, 107.26, $66.41,41.41,14.71,13.41 . \mathrm{IR}\left(\mathrm{KBr}, \mathrm{v} \mathrm{cm}^{-1}\right): 3479$, 1569, 1482, 1348, 1320, $1073 \mathrm{~cm}^{-1}$. HR mass Calcd. for $\mathrm{C}_{17} \mathrm{H}_{16} \mathrm{~F}_{3} \mathrm{~N}_{3} \mathrm{OS}$ : 367.1. Found: $m / z 368.1(\mathrm{M}+\mathrm{H})^{+}$.

1-Thiocarbamoyl-3-(2,5-dimethylfuran-3-yl)-5-(4(trifluoromethyl)phenyl)-2-pyrazoline (4f)

${ }^{1} \mathrm{H}$ NMR (300 MHz, DMSO- $\left.d_{6}, \delta, \mathrm{ppm}\right)$ : 2.22 (s, 3H, $\mathrm{CH}_{3}$ ), 2.43 (s, 3H, $\left.\mathrm{CH}_{3}\right), 3.07(1 \mathrm{H}$, dd, pyrazoline $\left.\mathrm{H}_{\mathrm{A}}, \mathrm{J}_{\mathrm{AB}}: 17.6 \mathrm{~Hz}, \mathrm{~J}_{\mathrm{AX}}: 3.7 \mathrm{~Hz}\right), 3.91(1 \mathrm{H}$, dd, pyrazoline $\left.\mathrm{H}_{B}, J_{A B}: 17.7 \mathrm{~Hz}, \mathrm{~J}_{\mathrm{BX}}: 11.64 \mathrm{~Hz}\right), 5.95$ $\left(1 \mathrm{H}\right.$, dd, pyrazoline $\mathrm{H}_{\mathrm{x}}, \mathrm{J}_{\mathrm{Ax}}$ : $\left.3.6 \mathrm{~Hz}, \mathrm{~J}_{B \mathrm{X}}: 11.64 \mathrm{~Hz}\right)$, 6.39 (s, 1H, furyl-H), 7.32-7.34 (m, 2H, Ar-H), 7.62 (b, $1 \mathrm{H}, \mathrm{NH}), 7.68-7.70(\mathrm{~m}, 2 \mathrm{H}, \mathrm{Ar}-\mathrm{H}), 7.99(\mathrm{~b}, 1 \mathrm{H}$,
$\mathrm{NH}) .{ }^{13} \mathrm{C}$ NMR (75.46 MHz, DMSO- $d_{6}$, ä, ppm): $175.90,151.81,150.71,149.71,146.80,129.10$, 127.34, 127.14, 125.03, 125.49, 124.21, 113.10, $107.26,66.61,41.10,14.71,13.41 . \mathrm{IR}\left(\mathrm{KBr}, \mathrm{v} \mathrm{cm}^{-1}\right)$ : 3444, 1594, 1478, 1367, 1324, $1064 \mathrm{~cm}^{-1}$. HR mass Calcd. For $\mathrm{C}_{17} \mathrm{H}_{16} \mathrm{~F}_{3} \mathrm{~N}_{3} \mathrm{OS}$ : 367.1. Found: $m / z 368.1$ $(\mathrm{M}+\mathrm{H})^{+}$.

\section{CONCLUSION}

In conclusion, we have developed a simple, rapid and efficient green synthesis of 1-thiocarbamoyl-3-(2,5-dimethylfuran-3-yl)-5(fluoro/trifluoromethylphenyl)-2-pyrazolines from commercially available acetylacetone in good yield under mild reaction condition. Microwave irradiation solvent-free method shortened the reaction time and improves yield of products (5-8 $\mathrm{min}$. and $69-84 \%$ ) than conventional method (5-6 hr and 54-64\%). The synthesized compounds were evaluated for their in vitro antimicrobial activity against various pathogenic bacterial and fungal strains. Compound 4b showed valuable inhibitory activity against most of the microbial strains compared with standards.

\section{ACKNOWLEDGMENTS}

The authors are gratefully acknowledged to Hi-Tech research foundation, Tharangambadi, Tamilnadu, India for providing the financial and laboratory facilities. Authors also thank Sophisticated Test \& Instrumentation Centre, Cochin University of Science and Technology, Cochin, Kerala, India for spectral studies.

\section{REFERENCES}

1. Sangapure, S. S., Bodke, Y., Raga, B., Ind. J. Heterocycl. Chem., 2001, 11, 31-37.

2. Rishiram, P., Janmajoy, B., Hemanta, K., Orient. J. Chem., 2015, 31(4), 2099-2106.

3. Gupta, U., Sareen, V., Khatri, V., Chug, S., Ind. J. Heterocycl. Chem., 2005, 14, 265-266.

4. Ashish, K.T., Anil, M., Verma, H. N., Mishra, A., Ind. J. Chem.,2006, 45B, 489-492.

5. Sivasanker, R.L., Rajkumar, T., Lakshmi, M.G., Sivarami, R.Y., Orient. J. Chem., 2015, 31(Spl Edn.), 189-199.

6. Makhsumov, A. D., Dzhurae, K. G., Nikbae,
A. T., Pharm. Chem. J., 1986, 20, 289-291.

7. Chetan, B.P., Mulwar, V.V., Ind. J. Chem.,2000, 44B, 232-237.

8. Nimavat,K.S., Popat, K.H., Ind. J. Heterocycl. Chem.,2007, 16, 333-336.

9. Udupi, R.H., Bhat, A.R., Krishna, K., Ind. J. Heterocycl. Chem., 1998, 8, 143-146.

10. Fabiane, R.S., Vanessa, T.S., Viviane, R., Lysandro, P.B., Marli, R.O., Helio, G.B., Nilo, Z., Marcos, A. P. M., Carlos, F. M., Eur. J. Pharmacol., 2002, 451, 141-147.

11. Ashok, K., Archana, Sharma, S., Ind. J. Hetero. 
Chem., 2001, 9, 197.

12. Varma, R. S., Microwaves in Organic Synthesis (A. Loupy, Ed.), Wiley-VCH, Weinheim Chapter 6, pp 181-218, (2002).

13. Hisashi, A., Koichi, F., Shoichi, K., Synlett, 2004, 6, 1049-1053.

14. Ameta, K. L., Varma, B. L., Indian Chem. Soc.,2002, 79, 840-841.

15. Mondal, R., M., Gupta, A. D., Mallik, A. K., Tetrahedron Lett., 2011, 52, 5020-5024.

16. Varma, R. S., Pure Appl. Chem.,2001, 73(1), 193-198.
17. Varma R. S., Tetrahedron.,2002, 58(7), 12351255.

18. Kulathooran, S., Selvakumar, B.,Dhamodaran, M., Der. Pharma. Chemica. 2014, 6(3), 240249.

19. Schelz, Z.,Molnar, J., Hohmann. J., Fitoterapia 2006, 77, 279-285.

20. Essam, M. S.; Nagwa, M. M. H. Am. J. Org. Chem. 2012, 2, 26-31.

21. Rishikesh, V. A., Cendilkumar, A., Divakar, G., Ganesh, S. A., Rajesh, J. O., Saudi Pharm J., 2011, 19, 233-243. 